\title{
Going nowhere: Routines in a pandemic
}

They walked with a strange gait, slowly, gently lurching. They wept silently, copiously, unable to see through their tears. They had tried to look into the future, overreaching the limits of human knowledge, and this was their punishment. Their heads were fixed backwards on their necks. They could not look forwards. They were the gathering of diviners, astrologers and magicians that Dante saw as he journeyed into the eighth sphere of Hell. Their plight made him cry. ${ }^{1}$

On the second Sunday of March, 1613, Richard Napier, one of England's leading astrologerphysicians, had a relatively quiet day. Messages from his patients began to arrive in the afternoon. He recorded their queries in notebooks as he sat at his desk in the parsonage in the Buckinghamshire village where he had held a living for two decades. Goody Ellen Pye's pain had grown worse. She was the wife of the baker, Thomas, in a nearby village, and had first consulted Napier the summer before, in August 1612, to ask whether she was pregnant. ${ }^{2}$ She was, and the child had been born in February. Two weeks later, she had consulted Napier about 'a great ach \& stitch under left syde' that 'maketh her to goe double'. ${ }^{3}$ A week later, his remedies had not helped. She 'cryes \& shrikes with the extremity of pain', has a quotidian fever, eats little. ${ }^{4}$ She survived into her 60 s, only occasionally consulting Napier, and either escaping or enduring the pain that had been with her on her initial consultation. An hour after Goody Pye's consultation on that Sunday in March, Alexander Warren, who had consulted Napier a month before with a case of the King's Evil, a swelling in the cheeks from which he'd suffered for a few years and was now impeding his ability to hear and eat, sent news of his condition. He'd been let blood and taken a purge that didn't work. He'd heard that the new wells held great promise of a cure. ${ }^{5}$ Then a letter from Sir Anthony Tyrringham, Napier's cousin by some remove and one of his regular patients, arrived to say that his illness of head and stomach was slowly mending. His request that the astrologer-physician visit him the day before need not be heeded, since he'd heard that Napier himself was ill and he did not wish to exacerbate his condition. ${ }^{6}$ Half an hour later, Napier was consulted-perhaps in person, perhaps by messenger - by Dorothy Laughton, a fifty-year-old woman from a village ten miles away. Napier simply noted, 'Hath them but very litle for she is old.' 'Them' is her menses. He prescribed a simple remedy. ${ }^{7}$ This was the only time that Laughton, or any of her family or friends, as far as we know, consulted Napier.

The next day, on the second Monday in March 1613, Napier saw no clients until 4pm when an ailing John Thorpe was brought to him on a cart. He'd suffered from incontinence, a couple of days before, he had become costive and developed a cough and cold and couldn't

\footnotetext{
${ }^{1}$ Dante Alighieri, The Divine Comedy: The Vision of Paradise, Purgatory and Hell, trans. H. F. Cary, Project Gutenberg, 2005, http://www.gutenberg.org/files/8800/8800-h/8800-h.htm, accessed 25 October 2020, Hell (Or the Inferno), Canto XX.

${ }^{2}$ Lauren Kassell, Michael Hawkins, Robert Ralley, John Young, Joanne Edge, Janet Yvonne Martin-Portugues, and Natalie Kaoukji (eds.), 'CASE40191', The Casebooks of Simon Forman and Richard Napier, 1596-1634: A Digital Edition, https://casebooks.lib.cam.ac.uk/cases/CASE40191, accessed 25 October 2020. Hereafter only case, note and person numbers are given. Original spelling and punctuation have been retained, except where necessary for clarity. Contractions have been silently expanded.

${ }^{3}$ CASE41000.

${ }^{4}$ CASE41030.

${ }^{5}$ CASE41031.

${ }^{6}$ CASE41032.

${ }^{7}$ CASE41033.
} 
sleep. That morning he'd lost the use of his legs. Napier paid particular attention to the planetary positions - Jupiter was in the ascendant - and observed, ' $\&$ his legs now sweld. \& is very poor $\&$ hath on his body like pimples but reddish. \& now blackish / his backe very blacke'. ${ }^{8}$

On the second Sunday of March, 2020, I boarded a flight from Philadelphia to Heathrow and landed the following morning. I had come home three months early from a semester teaching at Hopkins. That Monday I began to reassemble my Cambridge life, just as the days before, I had dismantled my US plans. I collected the dog. I went to the local shop to buy basic supplies, all attention on my oft-sanitised, germ-laden hands. I bundled away the belongings of my tenant who had left in a hurry to fly home to Norway before the border shut. My friends accepted that I wouldn't hug them, but were surprised at my reluctance to linger over a cup of tea in their kitchen. My twenty-first-century life spread across three continents-my partner in Hong Kong, my children and my job in the UK, my father and my sisters in the US — had changed. Maybe it had ended.

Tuesday was a busy day for Napier. At 8am John Walduck consulted him about swooning and stomach problems that had lasted a month. ${ }^{9}$ Sometime during the day, Napier calculated a nativity for Young Lady Dorothy Temple, one of his regular clients, who suffered from convulsions. ${ }^{10}$ At 2:30pm Sir Francis Fortescue consulted Napier about something that didn't merit recording. ${ }^{11}$ At 3 pm Elizabeth Hitchcock asked Napier if she was pregnant, and because (to simplify) Jupiter, lord of the fifth house, was in the ascendant, he concluded that she was. ${ }^{12}$ Also at $3 \mathrm{pm}$, perhaps suggesting that this is what time their messages or messengers arrived, Mr White consulted Napier for a remedy for his mother and Briant Clark sought help for an ague. ${ }^{13}$ Napier's first patient on Wednesday, at 11:45am, was Francis Howe, age 74, who asked him about a sore head and a 'deadish' finger. ${ }^{14}$ At $2 \mathrm{pm}$, again perhaps he received or opened a series of messages after lunch, Goody North asked about an unspecified complaint, and John Sharpe asked about a long illness with symptoms of sleeplessness, vomiting, dryness, and alternating hot and cold. ${ }^{15}$ Napier concluded that he had a quartan ague and prescribed a tablet. On Thursday, Napier's work began at 8:30am, with a consultation with Mrs Grigs, 'often ill \& of long tyme', who on this occasion reported sore limbs, a burning gut, sleeplessness, and inability to eat. Napier observed that her urine was 'like well water.' ${ }^{16}$ A little while later, Mr Neale's coach-delayed overnight due to a broken axle-finally arrived to take his wife home. ${ }^{17}$ She had been staying at the rectory and receiving Napier's treatment since January. ${ }^{18}$ Napier was planning a trip away. Sometime that day, he had sent a letter to Gerence James, his former curate and astrological assistant, who now held a living in a village half a day's ride away, to ask him to come to look after his household, and his practice, in his absence. ${ }^{19}$

\footnotetext{
${ }^{8}$ CASE41034. Perhaps attached to this case, perhaps the next: 'Was imprisoned by his owne daughter for debt. Made his will. A black dunnish water.'

${ }^{9}$ CASE41035.

${ }^{10}$ CASE41036.

${ }^{11}$ CASE40138.

${ }^{12}$ CASE41037.

${ }^{13}$ CASE41039, CASE41040.

${ }^{14}$ CASE41041.

${ }^{15}$ CASE41042, CASE41043.

${ }^{16}$ CASE41044.

${ }^{17}$ NOTE5519.

18 NOTE5494, PERSON33508.

${ }^{19}$ NOTE5520.
} 
James clearly agreed. On Friday, his hand takes the place of Napier's in the casebooks. At 12:30pm William Sallowes asked about a sickness with scouring (diarrhea) and a burning mouth that he'd suffered for a week since hunting on a damp day. ${ }^{20} \mathrm{At}$ 12:45pm Mrs Mainwaring, one of Napier's regulars, asked about a great pain in her back. ${ }^{21}$ At 2:20pm John Page asked about a great pain in his belly and an inability to sleep. ${ }^{22}$ On Saturday at 11:45am, Thomas Pain asked about a pain in his belly_-'Tooke it with a surfett at Alhollowtide' - and a giddiness in his head. ${ }^{23}$ At noon, Margaret Finne asked about a great flux of whites and reds (vaginal discharges) that she'd suffered since the previous summer, joined by pain around Christmas. ${ }^{24}$ At $5 \mathrm{pm}$ Charles Grey reported that the issue in his leg had healed and asked about 'A stincking flegme at his mouth and nose. ${ }^{25}$ On Sunday, James entertained a single case: at 7:30am, Jasper Henson asked about 'A great cough and stuffed with flegme / makes him very sicke.' And James observed, 'a high coloured thicke stinking urine. ${ }^{26}$ James continued to look after Napier's practice through the following week.

Napier was probably in London, where he would have visited with his brother and numerous friends and relations, perhaps bought books and other supplies, and conducted the occasional consultation inscribed on a loose sheet or in a small, portable notebook. ${ }^{27}$ His consultations required that he put pen to paper to compute the position of the stars at the time the question was asked, and he wrote less when he wasn't at his desk. His casebooks were diaries of his work, his domestic life, and his spiritual devotion.

Back at my house in March 2020, alone with the dog and in a self-imposed quarantine, I felt like a foreigner as I tried to understand the differences between US and UK coronavirus precautions. My Hopkins students helped me to master Zoom, and I in turn helped my Cambridge students. At my desk, I could be in two places at once. On Fridays, happy hour happened twice. I walked a lot, fixated on sourcing and conserving food, compulsively read Twitter on my phone, and busied myself in the kitchen to coincide with the BBC Radio 4 news schedule as though the plug-in radio next to the sink was an instrument of hope. I made tea before 9am, and scrubbed, chopped, cooked, snacked and tidied at 1pm, 5pm, and then, resentfully but devoutly, at 4:30, when the schedule shifted to accommodate government briefings.

Many people know that a symptom of grief is an inability to read. For me, it's not that the faculty of reading is impaired. I can read the news and emails and student work and even a typescript book. But the unmoored agitation of loss turns printed pages from vehicles of imagined escape into mazes to be traced and retraced, going nowhere. Long walks - that was my stock guidance for the bereaved, because I knew it worked. I was distracted, mourning something lost, but I wasn't bereaved. Death is certain, pandemic seems a byword for uncertainty. Long walks were part of my routine, through a beautiful town and old landscape where I'd lived for twenty years. Without the people - soon, once the weather was nice and everyone exercised their ration of lockdown walking, there would be too many people - a red brick wall told me that it remembered my small boys walking along its top and hawthorn flowers in a hedgerow spoke again hard words happily forgotten. I scared myself with the idea that I had wished this stillness on the world.

\footnotetext{
${ }^{20}$ CASE41045.

${ }^{21}$ CASE41046.

${ }^{22}$ CASE41047.

${ }^{23}$ CASE41048.

${ }^{24}$ CASE41049.

${ }^{25}$ CASE41050.

${ }^{26}$ CASE41051.

${ }^{27}$ For instance, CASE25895, CASE25896.
} 
My fellow historians of medicine were in the news. The Black Death, measles, cholera, the 1918 flu, polio, AIDS. What is the narrative, where do pandemics end, they were asked. ${ }^{28}$ We are not futurologists, some argued; others said we should be. ${ }^{29}$ Did it have to be this way? Did the world have to stop? In the name of saving privileged lives, would anyone count the cost to workers in the global south, or children everywhere ${ }^{30}$ I agreed to do a live radio segment on astrology so long as it wasn't about covid-19 (it was cancelled when a real story broke), and I declined invitations to talk about plague. I read Felicity Callard's Twitter thread of her suffering, beginning with the 'strange painful dance' to avoid infecting her partner, accumulating symptoms - loss of taste and smell were new indicators - through lapses and relapses across weeks then months into what eventually coalesced into the concept 'long covid'. ${ }^{31}$ On 17 April, her Day 29, she wrote 'Your friend @literati sent you another message of love, saying how hard it must be to in the throes of this virus without medical let alone narrative anchors. The phrase caught you up short. Tens of thousands of people simultaneously stitching signs together.' In my early modern world, Napier's world, the ideas that symptoms make a disease, doctors work through observed signs, and words have power made sense. ${ }^{32}$

When Napier returned home and resumed his practice at the end of March 1613, he followed his usual routines. Consultations began around 8am, sometimes much earlier. A few more would follow in the afternoon. Some days he conducted a single consultation, most days ranged between two and eight, with numbers occasionally higher than ten. On Monday, 24 April, he conducted two dozen consultations between 6:40am and $7 \mathrm{pm} .{ }^{33}$ Patients asked about pains, vomiting, voiding of worms, fevers and fits, bleedings, swellings, pimples, itching, inability to eat, wind, congestion, constipation, shortness of breath, inability to stand,

\footnotetext{
28 For instance, Gina Kolata, 'How Pandemics End', New York Times, 10 May 2020, https://www.nytimes.com/2020/05/10/health/coronavirus-plague-pandemic-history.html, accessed 10 May 2020; Lawrence Wright, 'How Pandemics Wreak Havoc—and Open Minds', New Yorker, 20 July 2020, https://www.newyorker.com/magazine/2020/07/20/how-pandemics-wreak-havoc-and-open-minds, accessed 20 July 2020. See also David S. Jones, 'History in Crisis-Lessons for Covid-19', New England Journal of Medicine, 12 March 2020, https://www.nejm.org/doi/full/10.1056/NEJMp2004361, downloaded 13 March 2020; Jeremy A. Greene and Dora Vargha, 'How Epidemics End', Boston Review, 30 June 2020, http://bostonreview.net/science-nature/jeremy-greene-dora-vargha-how-epidemics-end, accessed 30 June 2020; The American Historical Association has compiled 'A Bibliography of Historians' Responses to COVID-19': https://www.historians.org/news-and-advocacy/everything-has-a-history/a-bibliography-of-historians-responsesto-covid-19.

${ }^{29}$ Guillaume Lachenal and Gaëtan Thomas, 'COVID-19: When History Has No Lessons', History Workshop, 30 March 2020: https://www.historyworkshop.org.uk/covid-19-when-history-has-no-lessons/, accessed 15 April 2020. See also, Hannah Marcus, 'What the Plague Can Teach Us About the Coronovirus', New York Times, 1 March 2020, https://www.nytimes.com/2020/03/01/opinion/coronavirus-italy.html, accessed 20 March 2020; Mary E. Fissell, 'From Bubonic Plague to Covid-19', Washington Post, 7 May 2020, https://www.washingtonpost.com/outlook/2020/05/07/coronavirus-bubonic-plague-london/, accessed 7 May 2020.

${ }^{30}$ Carlo Caduff, 'What Went Wrong: Corona and the World after the Full Stop', Medical Anthropology Quarterly, 21 July 2020, https://anthrosource.onlinelibrary.wiley.com/doi/10.1111/maq.12599, accessed 27 October 2020. See also Carlo Caduff and Yarimar Bonilla, 'Covid, Twitter, and Critique: An Interview with Carlo Caduff', http://www.americananthropologist.org/2020/07/02/covid-twitter-and-critique-an-interviewwith-carlo-caduff/, accessed 2 July 2020.

$31 @$ felicitycallard, beginning 30 March 2020, 9:05am. Felicity Callard, 'Very, Very Mild: Covid-19 Symptoms and Illness Classification', Somatosphere, 8 May 2020, http://somatosphere.net/2020/mild-covid.html/, accessed 27 October 2020.

${ }^{32}$ Lorraine Daston, 'Ground-Zero Empiricism', in 'Posts from the Pandemic', Critical Inquiry, 10 April 2020, https://critinq.wordpress.com/2020/04/10/ground-zero-empiricism/, accessed 27 October 2020.

${ }^{33}$ Kassell et al. eds., Casebooks, https://casebooks.lib.cam.ac.uk/search?f1-documenttype=Case::Entry;sort=sort-date;f2-date=1610-1619::1613::04::19;startDoc=21, accessed 25 October 2020.
} 
faintness, loss of senses and more. He listened to their complaints, charted the movements of the planets, inspected flasks of their urine, sometimes wrote down a label for their diseases, and prescribed his usual range of electuaries, pills, and purges. Some patients sought physic, others resisted it. Occasionally Napier noted that a child was born, or someone mended or died. Many cases are brief, some more elaborate.

On Easter Sunday at 2:30pm Lady Mary Harrington, age 26, sent a message. She had been ill for six weeks, and was now bedridden. Napier wrote,

First took her with a great swelling over all her body \& at the mouth of her stomache with a mighty working at her heart \& a great stopping in her chest. So that she could not fetch her wind but from the top of her stomach $\&$ hath an arising up to her throate ready to cast \& ready to stop her wind \& as if she had convulsions and cramps \& stitches all over her when she lifted up her armes to her head she feeleth a tingling in her toes $\wedge \&$ her blood doth stand in her knees^ $\&$ she doth looke purple $\&$ blackish. She doth feare yt her legs doe consume away, sometimes seemeth to mend \& suddenly falleth back agayne. Has bene purged \& let blood \& hath taken a vomyt. \& more she is to take. Would know consell \& wheather there be any danger of death or no. Urine very good but thin some white dregs, \& mutch wyndynes.

Napier concluded, 'It will doe her good for the tyme but she will kinker [cough, as in hooping-cough] \& dye of a consomption halfe a yere hence. ${ }^{34}$ He did not record what he told her.

John Gibbs consulted Napier twice in August. He asked why he was lame in his hucklebone (hip), with pain in his lower back and calves. He reported that he had had this condition before, and 'Thinketh he is planet striken. ${ }^{35}$ He would consult Napier about his pain again many years later, in 1622, and again in $1628 .{ }^{36}$ Some of Napier's patients returned to him, often at long intervals, until he stopped practising at the very end of his life.

On 25 August, Napier recorded cases at 5:45am, 7am, 7:20am, and 3:30pm (figure 1) ${ }^{37}$ Then, with the exception of a handful of cases in his pocketbooks, his records stopped. They resumed again nine months later, on Friday, 20 May, at 8am when Richard Weatherhead asked him about a hot rheum and itchy eyes. ${ }^{38}$

As I settled into routines of distanced sociability in spring 2020, first with my younger son as a housemate, then with my partner home for the summer, I rooted my days in Napier's records. I had known about Napier's nine months of missing notes for several years. I had hoped for time to work out why they were missing, but immediate deadlines and commitments always took priority. Now, open to distraction from a book deadline at the end of the summer, I had unplanned days, punctuated by emergency budget meetings in the college and teaching meetings in the department. I looked forward to weekly collections of vegetables and, further into the fens, fortnightly provisions of eggs and chickens, to be handed over without touching across friends' doorsteps. Conversation had become unnatural. I was given tomato and courgette seedlings and a grow bag. On one delivery I collected a packet of yeast, passed on, with a rare bag of flour, at my next stop. I don't bake.

I didn't know whether Napier's routines had been interrupted by illness or doubt, whether he had quit, or whether his records had been lost or destroyed. I still don't know for certain, though I think he continued to see his patients and to write his casebooks day by day.

\footnotetext{
${ }^{34}$ CASE41119.

${ }^{35}$ CASE41724, CASE41757.

${ }^{36}$ CASE54004, CASE66717.

${ }^{37}$ Kassell et al. eds., Casebooks, https://casebooks.lib.cam.ac.uk/search?sort=sort-date;f1-date=16101619::1613::08::25, accessed 25 October 2020.

${ }^{38}$ CASE23394.
} 
I like to imagine the intrigues and infidelities, human and divine, that would have led him or someone else to set this great wodge of pages apart from the security of their compatriots. Perhaps someone deliberately destroyed them. In a world where the baker's wife was called Goody Pye and a man called Weatherhead suffered from ocular storms, it's hard to resist imagining magical adventures. Whatever happened, nine months of Napier's life, measured in nine months of his written days, are lost. I traced the paths of his pen from March to September, and then I found the page where they begin again in May 1614 the following year. Maybe everything will begin again in May 2021.

When I was invited to write this in July, I knew that I would gather materials from Napier's archive. I did not anticipate the contortions necessary to traverse the brief span between the present and the immediate past. It is not my habit to revisit my old calendars and or to trawl Twitter, the ultimate auto-archive. Perhaps as a historian I am not a diviner because even when I trade in hours and days, I am delighting in working out what things mean, not what has happened in the past nor what will happen in the future.

Lauren Kassell

Cambridge, England

26 October 2020

\section{Caption}

Figure 1. Napier's casebook for 25 August 1613. Oxford, Bodleian Library, MS Ashmole 199, f. 191v, from Lauren Kassell, Michael Hawkins, Robert Ralley, John Young (eds.), The Manuscripts of Simon Forman's and Richard Napier's Casebooks, 1596-1634:

https://cudl.lib.cam.ac.uk/view/MS-ASHMOLE-00199/406, accessed 11 November 2020. By permission of the Bodleian Libraries, University of Oxford. 